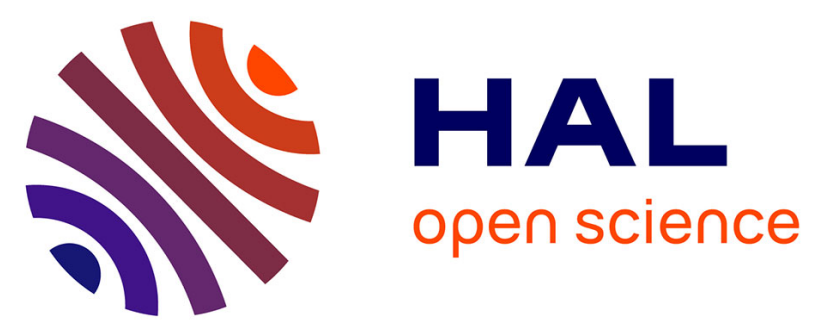

\title{
Acclimation of earthworms to chemicals in anthropogenic landscapes, physiological mechanisms and soil ecological implications
}

Nicolas Givaudan, Claudia Wiegand, Barbara Le Bot, David Renault, Frédérique Pallois, Stéphanie Llopis, Françoise Binet

\section{To cite this version:}

Nicolas Givaudan, Claudia Wiegand, Barbara Le Bot, David Renault, Frédérique Pallois, et al.. Acclimation of earthworms to chemicals in anthropogenic landscapes, physiological mechanisms and soil ecological implications. Soil Biology and Biochemistry, 2014, 79, pp.49-58. 10.1016/j.soilbio.2014.01.032 . hal-01005821

\section{HAL Id: hal-01005821}

https://hal-univ-rennes1.archives-ouvertes.fr/hal-01005821

Submitted on 13 Jun 2014

HAL is a multi-disciplinary open access archive for the deposit and dissemination of scientific research documents, whether they are published or not. The documents may come from teaching and research institutions in France or abroad, or from public or private research centers.
L'archive ouverte pluridisciplinaire HAL, est destinée au dépôt et à la diffusion de documents scientifiques de niveau recherche, publiés ou non, émanant des établissements d'enseignement et de recherche français ou étrangers, des laboratoires publics ou privés. 
Acclimation of earthworms to chemicals in anthropogenic landscapes, physiological mechanisms and soil ecological implications

3

4 Nicolas Givaudan $^{\text {a,b,c }}$, Claudia Wiegand ${ }^{\mathrm{a}, \mathrm{b}, \mathrm{c}}$,Barbara Le Bot ${ }^{\mathrm{b}, \mathrm{d}, \mathrm{e}}$, David Renault ${ }^{\mathrm{a}, \mathrm{b}}$, Fredérique 5 Pallois ${ }^{\mathrm{a}, \mathrm{b}}$, Stéphanie Llopis ${ }^{\mathrm{a}, \mathrm{b}}$, Françoise Binet $*^{\mathrm{a}, \mathrm{b}}$

6

a) University Rennes 1, UMR CNRS Ecobio 6553, Campus de Beaulieu, 265 Avenue du Général Leclerc, 35042 Rennes Cedex, France

b) Université Européenne de Bretagne (UEB), 5 Boulevard Laënnec, 35000 Rennes, France

c) University of Southern Denmark, Institute of Biology, Campusvej 55, 5230 Odense M, Denmark

d) EHESP Rennes, Sorbonne Paris Cité, Avenue du Professeur Léon Benard, CS74312, 35043 Rennes Cedex, France

e) Inserm, U 1085, IRSET, LERES, Avenue du Professeur Léon Benard, CS74312, 35043 Rennes Cedex, France

* Corresponding author: at University Rennes 1, UMR CNRS Ecobio 6553, Campus de Beaulieu, 265 Avenue du Général Leclerc, 35042 Rennes Cedex, France. Phone: +33223236665 , Fax : +3323236828

Email adresses :

nicolas.givaudan@univ-rennes1.fr (N. Givaudan)

wiegand@biology.sdu.dk (C. Wiegand)

Barbara.LeBot@ehesp.fr (B. Le Bot)

david.renault@univ-rennes1.fr (D. Renault)

frederique.pallois@univ-rennes1.fr (F. Pallois)

stephanie.1lopis@univ-rennes1.fr (S. Llopis)

francoise.binet@univ-rennes1.fr (F. Binet) 
36 Because earthworms sustain soil functioning and fertility, there is a need to advance the knowledge of their adaptation potential to chemicals in anthropogenic landscapes. Our hypothesis is that there is acclimation to organic chemicals (pesticides) in earthworms that durably persist under conventional farming in anthropogenic landscapes. The adaptation capability of two populations of earthworms (Aporectodea caliginosa)having a different chemical exposure history, - one originating from 20 years of organic farming (naïvepopulation) and another from 20 years of conventional farming (pre-exposed population)- to cope with soil organic pollutant (Opus ${ }^{\circledR}$, epoxiconazole a worldwide used fungicide) were investigated. Several complementary metabolic and energeticendpointswere followed, and cast production was assessed as a behavioral biomarker related to earthworms ecological role for the soil.Basal metabolism reflected by respiration rate was increased in both fungicide-exposed worms compared to controls. Glycogen resources were decreased in the same proportion inthe two populations but more rapidly for the naïve( 7 days) than for the pre-exposed population (28 days). Soluble protein and most amino-acidscontents increased in the pre-exposed population only, suggesting a detoxification mechanism. Metabolomic profiles showed a cut-off between fungicide-exposed and control groups in the pre-exposed earthworms only, with an increase in most of the metabolites. Exposure to a low dose of epoxiconazole increased cast production of pre-exposed earthworms, and this resulted in an increase in pesticide disappearance. As far as we know, this is the first study which evidenced there is an acclimation to an agricultural chemical in earthworms derived from conventional farmingthat also relates to a change in their burrowing behaviour, and for which larger consequences for the soil ecosystem need to be addressed. This original finding is of major interest in the frame of ecosystem resilience to global changes. Whether this physiological adaptation is a general pattern of response against fungicides or other pesticides would need to be confirmed with other molecules and agricultural contexts.

\section{Keywords}

64 Land-use, Epoxiconazole, Earthworm adaptation, Energy storage, Metabolomic profile,Soil bioturbation 


\section{Introduction}

71 Often representing the largest animal biomass, earthworms are present in most terrestrial ecosystems and are considered as efficient ecosystem engineers as they actively modify the physical, chemical and biological properties of the soil (Binet et al., 1998; Bottinelli et al., 2010; Jones et al., 1997; Monard et al., 2008). They sustain several key ecosystem services by enhancing soil structure and nutrient cycling,and play a role in ecosytemic services such as water regulation, pollution remediation and primary production (Blouin et al., 2013). In anthropogeniclandscapes, soil biodiversity and mainly earthwormcommunities have to face disturbances by intensive land-usedue to agricultural practices such as ploughing and tillage, application of fertilizers and chemical pesticides(Paoletti, 1999; Thompson, 1971). The soil compartment is the primary sink for agricultural pesticides, as they are frequently applied several times a year.Concerning fungicides, a large part either do notreach itsplant target,or is washed off from treated foliage, leading to major losses to the soil. Bromilow et al(1999a)reported in a field study that only $30 \%$ of the fungicide sprays were intercepted by the barley crop.The frequent application of agricultural pesticides and the persistence of some of them eventually leads to increasing amounts of residual compounds in the soil, either as free or bound residues (Gevao et al., 2000; Mordaunt et al., 2005), which can be a threat to lumbricids species. It has been shown that abundance and diversity of earthworm communities are dramatically reduced by chemical and mechanical stress (Decaëns and Jiménez, 2002; Smith et al., 2008). Despite these impacts however, worm populations persist in conventionally (with pesticides usage) cropped fields, albeit in reduced numbers. Assuming that immigration rate is low in earthworm populations(Lavelle and Spain, 2001), this suggests that earthworm populations living in pesticide-polluted soils can cope withchronic chemical stress, either via avoidance behaviour or physiological resistance (Posthuma and Van Straalen, 1993).

A chronic exposure to contaminants for generations may allow adaptation to take place, by favouring individuals that are able to face them.Physiological adaptation, e.g. acclimation, implies that individuals have acquired a degree of tolerance after a pre-exposure to chemicals at some point of their life, which can be lost within a generation. Genetic adaptation to xenobiotics implies constitutive and hereditary mechanisms allowing tolerance such as overproduction of specific compounds, (Brausch and Smith, 2009), or alteration of a target or receptor (Fournier and Mutero, 1994).Such adaptations to metals have been studied in terrestrial invertebrates including earthworms(Donker et al., 1993; Gudbrandsen et al., 2007; 
103 Posthuma, 1990).However to the extent of our knowledge no attempt has been made to 104 evaluate adaptation processes in earthworms against organic pesticides.

105 Adaptation, either via physiological or genetically-mediated mechanisms, is an expression of 106 the speciesecological plasticity allowing protection against stresses. However, it isknown to 107 be costly in terms of metabolism and energy usage, especially when it involves over108 production of compounds such as protection enzymes (Calow, 1991). Increased metabolic 109 rate or increased energy allocation to detoxification mechanisms can be at the detriment of 110 energy storage, and thus impair otherfunctions such as reproduction and growth (Jansen et al., 111 2011; Yasmin and D'Souza, 2010). This is particularly important when animals are exposed to 112 low but chronic exposures, such as earthworms in agricultural fields, due to the persistence of 113 residues of pesticides in the soils for several years after application (Gevao et al., 114 2000).Available energy resources, as measured by main storage compounds, can then reflect 115 energy demands associated with different adaptation strategies. In the earthworm 116 Dendrobaena octaedra, Holmstrupet al(2011)reported high energetic costs reflected by 117 glycogen depletion of the internal regulation of $\mathrm{Al}$ and $\mathrm{Ni}$ metals. On a lower level of 118 organization, and possibly on a shorter timescale, metabolomics have recently been used in 119 ecotoxicology studies to investigate the responses of the metabolism to contaminants (Brown 120 et al., 2010; Bundy et al., 2008; Simpson and McKelvie, 2009), and we think they can be a 121 valuable tool to study adaptation to contaminants.

122 One of the most common cultures in Brittany (France) is winter wheat, with a mean number 123 of 6 pesticides applications per year, the majority of them being fungicides (Agreste, 2006). 124 In particular, members of the triazole family, which act by inhibiting the biosynthesis of 125 ergosterol, have attracted interest because of their high persistency in soils (Bromilow et al., 126 1999a, 1999b; Passeport et al., 2011), although data available on their toxicity is still scarce.

127 The toxicity of some fungicides, such as benomyl and carbendazim has been investigated in a 128 few studies in earthworms and enchytraeids, another important member of the soil biota. 129 Avoidance behaviour was reported in Enchytraeids following exposure to benomyl and 130 Carbendazim (Amorim et al., 2005). Holmstrup (2000) also reported a decrease of 131 reproductive rate in the earthworm Aporrectodea longa associated with a reduction in the 132 whole earthworm population.

133 Our aim was to testthe hypothesis that earthworms inhabiting soil under conventional land134 use have acquired tolerance to face the regularly applied fungicide epoxiconazole.The 135 response of in situ pre-exposed versus naïve earthworms when exposed to an environmentally 136 relevant dose of the fungicide were thus studied. We addressedwhether an adaptation was 
137 quantifiable in terms of main energy resources storageand metabolism (respiration and metabolites levels)by comparing these two pre-exposed and naïve earthworms, and if these physiological changes were associated with change of their soil bioturbation ability. Our results evidenced that there is a physiological adaptation to fungicide in the earthworms originated from the conventional cropped field, leading to a change in their burrowing behaviourand impacting the fate of pesticide in soil.

\section{Materials and Methods}

148 Earthwormsused in this study originated from two agricultural fields, one conventionally croppedand one cropped according to organic agriculture requirements. Both of these fields have been in theseagricultural management strategies for more than 20 years and are located in the same agricultural basin (Vézin-le-Coquet, Britanny, France). Soils are slightly acid silt-clay loams (conventional and organic field, respectively: Clay $14.8 \%$ and $16.6 \%$; Silt $71.6 \%$ and $71 \%$; Sand $13.6 \%$ and $12.4 \%$; organic matter $1.67 \%$ and $2.55 \%$; pH (water suspension) 6.4 and 6.9).The conventional field had been cropped under rotations of wheat/maize/leguminous for 20 years, and annuallytreated with pesticides. The fungicide epoxiconazole was used each year a cereal was planted. Epoxiconazole is a triazole fungicide present in twopesticides formulations (OPUS $®$ and OGAM $®$ ) and mainly used on wheat. The organic field has been under rotation with a cereal (2 years) / maize (1 year) /lucerne (3years) without any pesticides for 20 years, and was not tilled during the lucerne periods.

160 Soil used for the exposure experiment was collected from the first $30 \mathrm{~cm}$ of a permanent (since 1960 ) organic pasture (17.6\% clay, $69.3 \%$ silt, $13.1 \%$ sand, $4.0 \%$ organic matter, $\mathrm{pH}$ (water suspension) 6.0) located in the same area where no initial epoxiconazole residuals were detected (see method in 2.3). Upon retrieval, it was air-dried until it reached $14 \%$ of humidity, then sieved to remove all soil particles larger than $2 \mathrm{~mm}$ and kept in sealed containers (100 1) until used for the experiment.

166 Theendogeic species Aporretodea caliginosawas chosen for this experiment.Itis an environmentally relevant species for toxicological tests, since it is commonly found in agricultural fieldsand reported as a dominant species(Jordan et al., 2004; Lamandé et al., 2003; Nuutinen, 1992; Söchtig and Larink, 1992). Most standard ecotoxicity tests are conducted on epigeic species mainly with Eisenia fetida or Eisenia andrei, but these species 
171 lack ecological relevance since they are usually absent from agricultural fields (Dittbrenner et 172 al., 2010).Earthworms were collected by hand-sorting at the beginning of Spring 2012 from 173 the two fields. Adults (presence of a fully developed clitellum) and sub-adults (presence of 174 tubercula pubertatis) were usedand individual weights were recorded (Table 1). Upon 175 collection, they were brought back to the laboratory and maintained in the soil collected from 176 the field at $25 \%$ humidity until start of fungicide exposure.Before the experiment, the 177 earthworms were acclimatized for 14 daysin the test soil in the climatic room used for the 178 experiment (Conviron GR96; temperature: $15^{\circ} \mathrm{C}$; day/night cycle: $16 / 8 \mathrm{~h}$; humidity: $80 \pm 5 \%$ ).

181 Soil contamination: Epoxiconazole was applied ascommercial formulation OPUS® (125 g active ingredient $\mathrm{l}^{-1}$, obtained from BayerCropScience)diluted in distilled water at $0.1 \mu \mathrm{gg}^{-1}$ soil, which is equivalent to a predicted field concentration calculated for a field application rate of 125 g.ha ${ }^{-1}$ assuming a single application with an homogenous distribution and no crop interception in the top $5 \mathrm{~cm}$ of the soil (Dittbrenner et al., 2010). Soil spiking was conducted by manually adding $175 \mathrm{ml}$ of the diluted pesticide solution or distilled water (for the controls) on each $2 \mathrm{~kg}$ of soil at $14 \%$ water content (1.75 kg dry weight) reaching a final soil water content of $24 \%$. To insure homogeneity of pesticide distribution in the soil, the solution was added in two parts, the soil being thoroughly mixed, resieved using a $2 \mathrm{~mm}$ aperture and redisposed as a fine layer.Soil microcosms consisted of polycarbonate boxes (80mm x 50mm, Caubère, Yebles, France) with a lid pierced with tiny holes to ensure sufficient aeration. The microcosms were filled with $100 \mathrm{~g}$ of contaminated or control soil, then $0.2 \mathrm{~g}$ of dry grass meal was added to the surface of the soil. Then the microcosms were left two days in a cool dark room to ensure aeration of the soil after re-humidification. Water content was checked again in 3 additional control boxes and adjusted to $25 \%$ prior to introduction of animals, then checked again each week.

197 Experimental design: The experimental design is described in table 1. It comprised 11 specimensfrom each population (pre-exposed and naïve) for each treatment (epoxiconazole or control) and sampling time (7and 28 days) plus an initial control group at day 0 (unexposed). Prior start of exposure, each earthworm was rinsed in tap water, gently dried on filter paper, weighed and placed in individual Petri dishes for 48 hours for gut voiding. Then animals were transferred individually to the exposure microcosms (day 0) according to a size-class procedure, insuring a similar mean earthworm weight in each treatment. Soil was spiked with epoxiconazole at $0.15 \mu \mathrm{g} \cdot \mathrm{g}^{-1}$ soilor control soil.Exposure lasted for 7 and 28 days, with an 
205 initial control group of 11 individuals for each population (unexposed worms) at day 0. At 206 each sampling date, before use of the microcosms for cast production (see 2.5) and pesticide measurements (see 2.3), earthworms were removed from the soil taking care not to break the casts. 5 of them were used for respirometry assessment (2.4), energy resources (2.6), and metabolites measurements (2.7). The other 6 earthworms were used for enzyme activities measurements in another study and will not be considered here. After the worms have been sampled, 8 microcosms were used for cast production measurements, and 3 for pesticide 212 analysis.

213 In addition, eight uncontaminated soil microcosms withoutworms were used as controls for 214 the cast production test to assess the potential formation of non-biogenic aggregates at 7 and 21528 days. Another 3 soil microcosms were filled with contaminated soil to track the fate of 216 pesticide without the presence of worms.Humidity control was conducted in 3 additional, 217 non-contaminated soil microcosms, in order to adjust humidity when necessary.

\begin{tabular}{|c|c|c|c|c|c|c|}
\hline & & \multirow{2}{*}{$\begin{array}{l}\text { worms } \\
\text { at start }\end{array}$} & \multicolumn{3}{|c|}{$\begin{array}{c}\text { Sampling days and } \\
\text { number of worms sampled }\end{array}$} & \multirow{2}{*}{ treatment } \\
\hline & & & 0 & 7 & 28 & \\
\hline \multirow{4}{*}{$\begin{array}{c}\text { Microscosms } \\
\text { containing one } \\
\text { earthworm }\end{array}$} & \multirow{2}{*}{$\begin{array}{l}\text { Pre-exposed population } \\
\text { (conventional field) }\end{array}$} & 33 & 11 & 11 & 11 & CTRL \\
\hline & & 22 & 0 & 11 & 11 & EPOXI \\
\hline & \multirow{2}{*}{$\begin{array}{l}\text { "Naïve" population } \\
\text { (organic field) }\end{array}$} & 33 & 11 & 11 & 11 & CTRL \\
\hline & & 22 & 0 & 11 & 11 & EPOXI \\
\hline \multirow{3}{*}{$\begin{array}{c}\text { Microcosms } \\
\text { without } \\
\text { earthworm }\end{array}$} & $\begin{array}{c}\text { Control microcosms for } \\
\text { cast production }\end{array}$ & 0 & 8 & 8 & 8 & CTRL \\
\hline & $\begin{array}{l}\text { Control microcosms for } \\
\text { pesticide dissipation }\end{array}$ & 0 & 3 & 3 & 3 & EPOXI \\
\hline & $\begin{array}{l}\text { Control microcosms for } \\
\text { humidity check }\end{array}$ & 0 & 3 & 3 & 3 & CTRL \\
\hline
\end{tabular}

219 Table 1: Experimental design of the laboratory exposure. Out of each group of 11 microcosms containing one

220 earthworm, 5 randomly picked worms were used for respirometry assessment, energy resources, and metabolite 221 measurements.

225 Sub-samples of $2 \mathrm{~g}$ of soil were retrieved the day of the pollution (day 0 ), and after 7 and 28 226 days, from three randomly chosen microscoms out of the 11 replicates. They were dried at $22730^{\circ} \mathrm{C}$ overnight, then kept frozen until pesticide analysis.Epoxiconazole in soil sub-samples 228 was measured by liquid chromatography coupled with mass spectrometer (LC-MS)(Waters alliance 2690, Waters, Saint Quentin en Yvelines, France). 2g of soil sample were extracted in $500 \mathrm{ml}$ of mineral water. After $15 \mathrm{~min}$ of ultrasound treatment, the sample was mixed by 
231 rotary shakingfor one hour, and subjected to another $15 \mathrm{~min}$ of ultrasound treatment. $0.25 \mu \mathrm{g}$ 232 of triadimenol was added as internal standard and $1 \mathrm{ml}$ of analytical-grade nitric acid $\left(\mathrm{HNO}_{3}\right)$ 233 to acidify the mixture. Then pesticides were extracted from the aqueous mixture in two steps 234 with $25 \mathrm{ml}$ of HPLC-grade dichloromethane followed by $15 \mathrm{~min}$ of agitation. The dichloromethane extracts were combined and evaporated to a drop (ca. $10 \mu \mathrm{l}$ ), then $500 \mu \mathrm{l}$ acetonitrile were added and $0.25 \mu \mathrm{g}$ of pentabromophenol were added as second internal standard. The extract was evaporated again to a drop and adjusted to $500 \mu \mathrm{l}$ with $10 \%$ acetonitrile acidified ( $0.1 \%$ formic acid).

239 This sample was analysed by LC-MS using a high-performance liquid chromatography 240 (Alliance 2695, Waters, Saint Quentin en Yvelines, France) coupled to a quadrupole mass 241 spectrometer model ZQ (Waters-Micromass, Saint Quentin en Yvelines, France) equipped 242 with an electrospray source. Epoxiconazole was separated on a X Terra MS C18 column (150 $243 \times 2.1 \mathrm{~mm}, 3.5 \mathrm{~mm}$ particle size, Waters, Saint Quentin en Yvelines, France) at $35{ }^{\circ} \mathrm{C}$. A 244 binary mobile phase gradient (A: ultrapure water with $0.1 \%$ formic acid; B: acetonitrile with $2450.1 \%$ formic acid) was used for pesticide separation. The chromatographic method held the 246 initial mobile phase composition $(82 \% \mathrm{~A}, 18 \% \mathrm{~B})$ constant for $10 \mathrm{~min}$, followed by $70 \% \mathrm{~A} /$ $30 \%$ B (10min), 50\% A / 50\% B (15 min), 20\% A-80\% B (5 min), then again 82\% A / 18\% B for $10 \mathrm{~min}$. Quantification limit was $2.5 \mathrm{ng} . \mathrm{g}^{-1}$ dry soil and extraction yield was $75 \pm 7 \%$. A standard curve of epoxiconazole was made with several aliquots of $2 \mathrm{~g}$ of dry soil (the same uncontaminated pasture soil used for the microcosms) spiked manually with the purified compound, air-dried for two hours, and extracted the same way as the real samples for quantification, relating to the two internal standards. Pesticides analytical standards were purchased from Dr Ehrenstorfer (Ausburg, Germany).

254 Recovery of epoxiconazole in spiked soil was initially $80 \%$ of the desired concentration $(0.1$ $\mu \mathrm{g} \cdot \mathrm{g}^{-1}$ ), with a coefficient of variation of $10 \%$, which was considered highly satisfactory, as we used the commercial formulation of the pesticide. Concentrations of epoxiconazole in soil (Table 2)were still two thirds of the initial concentration after 28 days, which is consistent with the long persistencies (half-life > two years) reported in the literature (Bromilow et al., 1999a, 1999b; Liang et al., 2012).

After 7 and 28 days of exposure, earthworms were removed from the soil microcosm, rinsed, gently blotted dry on filter paper, weighed and left 24 hours in a $250 \mathrm{ml}$ glass jar on a moist 
265 filter paper for gut voiding. Thereafter, the glass jar was hermetically closed for two hours, 266 and $\mathrm{CO}_{2}$ was measured by a Micro-Gas Chromatograph (3000A, SRA Instruments) equipped 267 with a single capillary column Poraplot $U$ and coupled with a thermal conductivity detector.

268 Then the worm was frozen in liquid nitrogen for further measurements of energy resources 269 (2.6) and metabolomics (2.7).

\subsection{Cast production}

Cast production was measured in the soil of 8 microcosms out of the 11 replicates. The cast production test was conducted according to the protocol of Capowiez et al. (2010) but using a sieve of mesh size $2 \mathrm{~mm}$. Soil of the microcosms were dried at $40^{\circ} \mathrm{C}$ overnight, and sieved by shaking the sieve consistently for $10 \mathrm{~s}$.

\subsection{Energy resources measurement}

Frozen worms were freeze-dried, and ground to a fine powder by multiple $30 \mathrm{sec}$ agitations with inox beads in $2 \mathrm{ml}$ test tubes in a bead-beater (Retsch MM400, Retsch GbmH, Haan, Germany). Each ground sample was separated in several aliquots, $2 \mathrm{mg}$ for total lipids, $5 \mathrm{mg}$ for soluble proteins, and $2 \times 10 \mathrm{mg}$ for glycogen and metabolites measurements. Lipid aliquots were extracted according to Folch(1957), lipids in the chloroform extract were assayed by the sulfo-vanillin method with a calibration curve of commercial vegetable oil at $525 \mathrm{~nm}$. Proteins aliquots were homogenized in $0.1 \mathrm{M}$ phosphate buffer ( $\mathrm{pH}$ 6.5), centrifuged and measured according to Bradford (1976) using a calibration curve of bovine serum albumin. Glycogen was measured according to the method of Nicolaï et al(2012). Briefly, aliquots were homogenized in $600 \mu \mathrm{l}$ trichloroacetic acid (4\%) and centrifuged at $5000 \mathrm{G}$ (rotor $\mathrm{N}^{\circ}$ 12145, SIGMA, $8000 \mathrm{rpm}$ ) for 10 minutes. Then $500 \mu \mathrm{l}$ of supernatant was recovered and glycogen was precipitated by adding $1.5 \mathrm{ml}$ of ethanol and stirring for 10 minutes.The extract was centrifuged $(5000 \mathrm{G})$ and the ethanol eliminated with a glass pipette.

293 The pellet was washed with $2 \mathrm{ml}$ ethanol, then the remaining ethanol was totally evaporated at $70^{\circ} \mathrm{C}$. The pellet was redissolved by stirring it overnight in ultrapure water, and centrifuged again. Absorbance was measured at $425 \mathrm{~nm}$ with a microplate reader (Fischer Scientific Multiskan FC)after addition of Lugol using a calibration curve of purified glycogen (Oyster type II, Sigma). 
Metabolite extraction was conducted according to Khodayari et al(2013). The freeze-dried and ground sample was homogenized in $600 \mu \mathrm{L}$ of cold $\left(-20^{\circ} \mathrm{C}\right)$ methanol-chloroform $(2: 1)$ using a bead-beating device (Retsch MM301, Retsch GbmH, Haan, Germany). $400 \mu \mathrm{L}$ of icecold ultrapure water was subsequently added, and each sample was stirred. After centrifugation at $4000 \mathrm{G}$ for $10 \mathrm{~min}$ at $4{ }^{\circ} \mathrm{C}, 300 \mu \mathrm{l}$ of the upper aqueous phase, containing polar metabolites, were transferred to new chromatographic vials and vacuum-dried using a Speed Vac Concentrator (MiVac, Genevac Ltd., Ipswitch, England). The dried extracts were thenredissolved in $15 \mu \mathrm{L}$ of $20 \mathrm{mg} \cdot \mathrm{mL}^{-1}$ methoxyaminehydrochloride (Sigma-Aldrich, St. Louis, MO, USA) in pyridine, incubated under automatic orbital shaking at $40^{\circ} \mathrm{C}$ for $90 \mathrm{~min}$ prior to derivatization. Then, $15 \mu \mathrm{L}$ of $\mathrm{N}$-methyl-N-(trimethylsilyl) trifluoroacetamide (MSTFA; Sigma) was added, and derivatization was conducted at $40{ }^{\circ} \mathrm{C}$ for 45 min under agitation. The derivatization process was automatized using a CTC CombiPal autosampler (GERSTEL GmbH and Co.K.G, Mülheim an der Ruhr, Germany).

\subsubsection{GC-MS analyses}

Gas chromatography coupled with mass spectrometry (GC-MS) was used to measureup to 58 small metabolites belonging to different classes ofmolecules: amino-acids, polyols, sugars, intermediates of the citric acid cycle and other unclassified biological molecules. The GC-MS system was comprised of a Trace GC Ultra chromatograph, and a Trace DSQII quadrupole mass spectrometer (Thermo Fischer Scientific Inc, Waltham, MA, USA). The injector temperature was set at $250^{\circ} \mathrm{C}$. The oven temperature was increased from $70^{\circ} \mathrm{C}$ to $170^{\circ} \mathrm{C}$ at $5^{\circ} \mathrm{C} \mathrm{min}{ }^{-1}$, from 170 to $280^{\circ} \mathrm{C}$ at $7^{\circ} \mathrm{C} \mathrm{min}^{-1}$, from 280 to $320^{\circ} \mathrm{C}$ at $15^{\circ} \mathrm{C} \mathrm{min}^{-1}$, then the oven remained for $4 \mathrm{~min}$ at $320^{\circ} \mathrm{C}$. A $30 \mathrm{~m}$ fused silica column (TR5 MS, I.D. $2.5 \mathrm{~mm}, 95 \%$ dimethyl siloxane, 5\% Phenyl Polysilphenylene-siloxane) was used, with helium as the carrier gas at a rate of $1 \mathrm{~mL} \cdot \mathrm{min}^{-1}$ One microliter of each sample was injected using the split mode (split ratio: 25:1). We completely randomized the injection of the samples. The temperature of the ion source was set at $250^{\circ} \mathrm{C}$ and the MS transfer line at $300^{\circ} \mathrm{C}$. Detection was achieved using MS detection in electronic impact (EI). We used the selective ionmonitoring mode (SIM) (electron energy: $-70 \mathrm{eV}$ ), allowing a precise annotation of the detected peaks. The peaks were identified according to both their mass spectra (two ions) and 
333 their retention times. Metabolite levels were quantified, if above their quantification limits,

334 according to calibration curves made with 58 pure reference compounds, including the 335 internal standard. Chromatograms were integrated using XCalibur v2.0.7 software (Thermo 336 Fischer Scientific Inc, Waltham, MA, USA).

340 For both populations, the effect of epoxiconazole compared to control groups, or mean 341 differences between populations, either on respiration, energy storage or cast production was tested by student-t-tests at each sampling time. The disappearance of pesticide in the soilwas tested by one-way ANOVA with time as factor for soils containing pre-exposed, naïve and no earthworms, followed by post-hoc tests according to the Tukey procedure. On the metabolomics data, two principal component analyses (PCA) were performed on each population as separate datasets on log-transformed and standardized variables. Three axes, explaining $70 \%$ of variability, were kept for interpretation. The variables Serine and Threonine were highly correlated (94\%) so their arithmetic sum was used in a single variable, so as not to hamper the results of the PCAs. A classification of the metabolites into "functional biochemical groups" was done following Bundy et al(2008) and based on biochemical knowledge. Amino-acids were classified either as lipophilic, hydrophilic or neutral. Regardingthe metabolite functional group responses to epoxiconazole, significant differences between control and exposed worms for each metabolite were tested by student-ttests at 7 and 28 days. Significance level for student-t-tests was set at $p \leq 0.1$.All analyses were conducted using the statistical software of " $\mathrm{R}$ 2.12.1" for Macintosh(R Development

356 Core Team, 2008).

\section{Results}

\subsection{Energy dissipation}

362 Fungicide treatment increased $\mathrm{CO}_{2}$ production in both pre-exposed and naïve populations 363 after 7 and 28 dayscompared to their non-treated controls(Fig 1). Respiration rate in the 364 fungicide-treated group was higher after 7 and 28 days compared to day 0 in the pre-exposed population. Differences became significant between populations at 28 days, where 
metabolicrates of the pre-exposed population (both exposed and control groups)werestill higher than at the outset, while it remained constant in the naïve population from day 7 to 28 .

\subsection{Cast production $(\mathrm{CP})$}

The weight of casts ( $\mathrm{g}$ of dry cast $\mathrm{day}^{-1}$ ) correlated linearly and positively to earthworm weights at 7 and 28 days $\left(R^{2}=0.34 ; p<0.001\right.$ and $R^{2}=0.33 ; p<0.05$, respectively, all modalities mixed). The cast production was then calculated as weight difference of non-biogenic aggregates retained in the sieve from the 8 control (without worms) microcosms to the ones with worms and expressed per gram of fresh worm. Worms from both populations displayed similar patterns with constantCP over time in control soil microcosm and significantly changed CP with fungicide treatment (Figure 2). Application of epoxiconazole transitory enhanced CP (7 days) in pre-exposed worms ( $\mathrm{p}<0.01)$, and slightly decreased it, however not significantly, after 28 days in bothworm populations.

\subsection{Energy resources}

Mean glycogen content was decreased by nearly $20 \mathrm{mg}$ in fungicide-treated compared to control groups after 7 days in the naïve earthworms, and after 28 days in the pre-exposed earthwormsas shown in (Figure 3-A). At the end of the exposure, theworms originating from the conventional-treated field had a slightly lower glycogen tissue level than the naïve ones. The lipid tissue levels (Figure 3-B) did not show any significant differences between unexposed and fungicide exposed earthworms or between earthworms originating from the conventional or the organic-treated field. Lipid levels were lower in all treated groups compared to their respective controls, however it did not achieve significance.Protein contents (Figure 3-C) decreased similarly in the 4 groups of worms during the first 7 days.They were then significantly increased by fungicide treatment in both exposed and naïve populations compared to their respective controls after 28 days, with pre-exposed worms having a final protein amount almost twice as high as naïve ones.

\subsection{Metabolomics}

Twenty eight metabolites were detected and quantified in the earthworm tissues. From this dataset, 22 were kept for interpretation (table 1). For the conventional population (Figure 4A), 
scores plots on axis 2 and 3 showed that the worms exposed for 28 days formed a separate

401 cluster from the 28 days control worms along axis 2 and 3. This pattern was not observed in the organicpopulation(Figure 4B) along any of the three axes, as it seems the time effect is greater than the fungicide effect. Indeed, the exposed and the control groups move in the same way with time, but are not clearly separated.

405

\subsubsection{Metabolic changes in the worms populations}

In the loadings plots of the PCAs (figure 4C and 4D), several coordinated responses were identifiable. In the conventional population (Figure 4C), the 7variables that have loadings lower than -0.5 on axis 2 form a first cluster containing mostly lipophilic amino-acids.Another clusteris in the lower half of the plot corresponding to variables having low loadings (roughly, $<-0.2$ ) on axis 3 , composed of the three sugars, succinate, ornithine, the amino-acids glycine and proline and putrescine.On the other hand in the organic population (Figure 4D), we see two clear clusters that could correspond to the incubation time: the top right corner for seven days and the top left corner for 28 days. Day zero would correspond to the sugars Glu and Rib (lower half). The induced changes in metabolite concentrations after exposure was then measured as normalized concentrations in percentage of the control value and compared according to functional groups (Figure 5). In the conventional worms, several metabolites increased after 28 days of epoxiconazole exposure in all four biochemical groups (aminoacids, sugars, organic acids and ornithine-putrescine), up to 7-fold for aspartate, 4-fold for aminobutyrate, and 2-fold for ornithine and putrescine.This general increase in metabolite levels was not observed in the naïve population, which displayed different trends. Indeed, in Figure 5E, certain amino-acids (Asn, Asp, Phe and Val) increased slightly, whereas othersdropped below $100 \%$ or stayed stable at 28 days.Not much variation was observed in organic acidsof the organic earthwormsat 28 days, except for aminobutyrate which dropped to $50 \%$ of the control value, contrasting to its 4-fold increase in the pre-exposed animals. Putrescine level increased by 2 -fold after 28 days in both populations whereas ornithine decreased to below $50 \%$ of the control value in the organic population only.

\section{Discussion}


434 Animals can tolerate pollutants via biotransformation, excretion or scavenging of free radicals 435 (when pollutants induce oxidative stress). For example, detoxification of several pollutants, 436 e.g atrazine or paraquat, is mediated via the enzyme Glutathione-S-Transferase. This enzyme, 437 belonging to phase II detoxification mechanisms, acts through binding xenobiotics to 438 glutathione and facilitating its excretion (Anderson and Gronwald, 1991; 2007, 2000). 439 Another common detoxification pathway to xenobiotics is the group of cytochrome p450 440 oxidases. This family of enzymes transform the structure of organic chemicals, hence greatly 441 altering their toxicity (Ribera et al., 2001; Rodríguez-Castellanos and Sanchez-Hernandez, 442 2007). However, no data on epoxiconazole tolerance pathways e.g. detoxification 443 mechanisms was available in the literature.

444 On the other hand, the literature suggests that there are energetic costs in organisms for coping with pollutants (Fisker et al., 2011; Holmstrup et al., 2011; Wiegand et al., 2007). The 446 way organisms handle energetic processes can therefore inform us on adaptation mechanisms. 447 As an example by measuring the main energy resources, Pook et al (2009) showed that a 448 metal-resistant population of marine harbour ragworm ( $N$. diversicolor) had a lower scope for 449 growth than a reference (non-resistant) population and demonstrated a metabolic cost, or tradeoff, of resistance.Other tradeoffs can be the co-selection of traits along with tolerance to xenobiotics, such as life history traits. Interestingly, in the conventionally cropped field, the worms sampled had a lower initial mean weight but with constant tissue composition compared to the organic worms (Table 1). This could be a result of the selection of smaller individuals, by the global agricultural management of the field, as a possible combined effect of fertilizers, pesticides and tillage (tillage was less frequent in the organic field due to the lucernecropping). This assumption is supported by the fact that the bigger anecic species such as L. terrestrisor A. giardiare usually the most impacted in cropped soil(Edwards and Bohlen, 1996).

459 To investigate such energetic costs, we measured the worm's metabolic rate $\left(\mu \mathrm{g} \mathrm{CO} 2 \mathrm{~g}^{-1}\right.$ worm (fresh weight) hour ${ }^{-1}$ )as a proxy ofenergy dissipation, and the main energy storage compounds which are glycogen (main sugar resource), total proteinsand lipids.Metabolic ratewas increased in both populations after 7 days of exposure, showing that the fungicide increased metabolic rate, but to a greater extent in the pre-exposed earthworms. Energy 464 dissipation in both control and exposed groups were indeed higher than the naïve earthworms after 28 days. The increase in putrescine and alanine observed in the twopopulations when exposed suggests a stress response in both groups of earthworms, these two metabolites have previously been suggested as universal biomarkers in metabolomics studies (Groppa and 
Benavides, 2008; Rhee et al., 2007; Simpson and McKelvie, 2009). However, the increase in

469 most amino-acids contents in the pre-exposed earthworms after 28 days, which is not observed in the naïve animals, indicates a particular metabolic response. Several studies reported that the available resources in amino-acids were at the centre of metabolic activity during stress responses (Krasensky and Jonak, 2012; Lankadurai et al., 2013; Simpson and McKelvie, 2009). Moreover, the increase in alanine, aspartate, aminobutyrate and succinate observed in the pre-exposed populations could indicate an activation of the alanine, aspartate and glutamate pathway (Kanehisa and Goto, 2000).

The increase in both metabolic rates was reflected by depletion in the lipid and the glycogen resource. However a temporal delay appeared in the glycogen usage, indicating a differential mobilisation of this sugar resource between naïve and pre-exposed earthworms. The naïve earthworms seem to consume glycogen earlier than the pre-exposed group. Glycogen breakdown is reflected by the slight increase of glucose in fungicide-exposed groups of earthworms after 28 days. Soluble proteins were also significantly higher after 28 days in the pre-exposed worms only, which could indicate the higher synthesis of detoxificationenzymes such as cytochrome p450(Lukkari et al., 2004). Metabolic profiles of control and exposed groups in pre-exposed earthworms became distinct after 28 days, indicating that metabolic networks have been rearranged to maintain internal homeostasis and performance of the organisms.

Overall, all these findings show that pre-exposition of earthworms over generations in the conventional farming system has led to physiological adaptation, as evidenced by their higher reaction to the fungicide. Other studies have shown that separation of metabolic signatures (PCA analyses) increase with higher doses of the pollutants, e.g DDT, endosulfan or copper (Bundy et al., 2008; Simpson and McKelvie, 2009). It is likely that, in our study, fungicide recommended application rate corresponds to a low sublethal dose and the differences in metabolic signatures would become clearer with higher concentrations of the pesticide. Nevertheless, the differences observed demonstrate an impact even at this environmentally realistic level. As both populations were selected from fields under long term (20 to 25 years) conventional and organic farming, an adaptation mechanism on the genetic level could be assumed, but would need to be proven. 
501 Several studies aimed to correlate biochemical or cellular responses in earthworms to 502 pollutants with ecologically important endpoints. For example, Maboeta et al. (2001) showed 503 that there was a link between decrease in the abundance of field populations of the earthworm 504 Microchaetus sp. and decrease in the animals' neutral red retention time (a biomarker of 505 cellular damage). By showing a strong reduction of earthworm growth by pesticides, (1992) 506 postulated that these contaminants were likely to cause a delay in sexual maturity in juveniles 507 and have eventually have an impact on earthworm abundance in the field. However, pesticide 508 impacts on burrowing behavior have only poorly been studied because of the difficulty to 509 visualize or estimate burrowing activity, and few studies have tried to link pollutant impacts 510 at low levels of organisation (cellular, biochemical) with earthworm burrowing (Capowiez et 511 al., 2010; Gupta and Sundararaman, 1991). With regard to the ecological importance of 512 earthworms through the burrowing of the soil, it is likely that, when attempting to assess the 513 ecosystem services rendered by earthworms to the soil, earthworm burrowing behaviour is as 514 important as population numbers as it can have drastic impacts for soil functioning (Capowiez 515 \& Bérard 2006).

516 Here, the low dose application of fungicideresulted in an increase in cast production after seven days, which is consistent with the recent results of Dittbrenner et al(2010), where cast 518 production was increased only at the lowest concentration of the pesticide, but decreased at 519 higher doses. The impacts of pesticides on soil bioturbation have been investigated in a few 520 articles using 2D and 3D (X-ray tomography) terraria, cast production method and the 521 avoidance behaviour test. Most of them, except for the paper of Dittbrenner et al (2010), have 522 shown a decrease in activity or an impact on the characteristics of the burrow systems, e.g 523 length, depth, and branching rate (Pelosi et al., 2013). Interestingly, in the present study, the 524 increase in cast production was only observed in the pre-exposed earthworms. Therefore it could suggest that tolerance to this environmentally realistic level of fungicide is associated 526 with a compensatory increased activity. This increase in burrowing behaviour could be 527 induced by the metabolic changes observed in energetic depletion and metabolites 528 rearrangements, similarly to the phenomenon of hormesis (Zhang et al., 2009). An alternative 529 hypothesis would be that it is related to avoidance behaviour, but unsuccessful, as the 530 earthworm is confined to the microcosm, resulting in an increased amount of casts. It is also 531 known that geophagous earthworms are able to alter their burrowing behaviour and display 532 different behaviours (in terms of soil ingestion) when they are feeding on organic matter in 533 the soil or moving through the soil (possibly as part of an avoidance response)(Capowiez and 534 Bérard, 2006; Hugnes et al., 1996). This may lead to reduced cast production in contaminated 
535 soils rather than increased cast production but it is dependent on the level of contamination 536 and the contaminant (Dittbrenner et al., 2010).

537 The fate of pesticides in soil can be affected by earthworms bioturbation via several 538 mechanisms. It increases pesticides sorption on soil particles on the long-term, leading to the 539 formations of non-extractable residues. Therefore it can increase the pesticide persistence, as 540 it was previously shown for atrazine (Binet et al., 2006; Farenhorst et al., 2000). On the other

541 hand, earthworms' activity was also reported to stimulate microorganisms activity, and 542 enhance the activity of atrazine- or MCPA-specific bacterial degraders, accelerating its 543 mineralisation (Liu et al., 2011; 2011, 2008). A. caliginosaalsoparticipated in the breakdown 544 of four fungicides (folpet, fosetyl-Al, metalaxyl, myclobutanil) and two insecticides 545 (Chlorpyrifos-Ethyl and $\lambda$-Cyhalothrin)(Schreck et al., 2008). In our study, pesticide 546 concentration is lower in the microcosms containing earthworms from the conventional field

547 (Table 2). The increase in bioturbation observed in these earthworm'smicrocosms suggest that 548 they play a part in the pesticide's disappearance either by enhancing sorption or by enhancing 549 microbial mineralization of epoxiconazole.

\section{5. Conclusion}

552 This study shows that an environmentally realistic concentration of epoxiconazole applied as 553 OPUS® induced distinct physiological changes in two populations of the earthworm $A$. 554 caliginosa.Biological responses in energy storage and metabolic profiles differed between 555 earthworms derived from conventional farming and those from organic farming, indicating 556 that an acclimation mechanism to the agricultural pesticide occurs in the long-term pre557 exposed animals. Theacclimationin pre-exposed animals was also evidenced by their higher 558 reaction to the chemical, withincreasedmetabolicrate and burrowingactivity compared to the 559 naïve animals, which ecological consequence is alower pesticide concentrationin the soil. 560 This original finding is of major interest in the frame of ecosystem resilience to global 561 changes. Whether this physiological adaptation is a general pattern of response against 562 fungicides or other pesticides would need to be confirmed with other molecules and 563 agricultural contexts.

\section{4}

\section{Acknowledgements}

567 The authors are grateful to Gabriel Nédelec and Philippe Leroy (INRA Rennes) and Christian 568 Mogis (GAEC La Mandardière, Pacé) for providing history of cultivation and access to their 
agricultural fields. Many thanks to Barbara Martineau (ECOBIO) and to Catherine Rouillon and Claude Briens (LÉRES) for their technical help during the microcosm experiment and the chemical analyses, respectively. The authors are also grateful to Hans Christian Petersen for providing statistical support and for the very constructive comments from both reviewers. This work was funded by the European University of Brittany (UEB) in the frame of the International Chair of Excellency in Agronomy and Environment granted to Claudia Wiegand and to ECOBIO laboratory. It is also part of the LIA "ETSE" sustained by the CNRS-INEE, the University of South Danemark (SDU) and the University of Rennes 1. The authors declare they have no conflicts of interest.

\section{References}

Amorim, M.J.B., R 2 mbke, J., Soares, A.M.V.M., 2005. Avoidance behaviour of Enchytraeus albidus: Effects of Benomyl, Carbendazim, phenmedipham and different soil types. Chemosphere 59, 501-510. Anderson, M.P., Gronwald, J.W., 1991. Atrazine Resistance in a Velvetleaf (Abutilon theophrasti) Biotype Due to Enhanced Glutathione S-Transferase Activity. Plant Physiol. 96, 104-109.

Binet, F., Fayolle, L., Pussard, M., Crawford, J.J., Traina, S.J., Tuovinen, O.H., 1998. Significance of earthworms in stimulating soil microbial activity. Biol. Fertil. Soils 27, 79-84.

591 Binet, F., Kersanté, A., Munier-Lamy, C., Le Bayon, R.-C., Belgy, M.-J., Shipitalo, M.J., 2006. Lumbricid macrofauna alter atrazine mineralization and sorption in a silt loam soil. Soil Biol. Biochem. 38, 1255-1263.

Blouin, M., Hodson, M.E., Delgado, E.A., Baker, G., Brussaard, L., Butt, K.R., Dai, J., Dendooven, L., Peres, G., Tondoh, J.E., Cluzeau, D., Brun, J.-J., 2013. A review of earthworm impact on soil function and ecosystem services. Eur. J. Soil Sci. 64, 161-182. Bottinelli, N., Henry-des-Tureaux, T., Hallaire, V., Mathieu, J., Benard, Y., Duc Tran, T., Jouquet, P., 2010. Earthworms accelerate soil porosity turnover under watering conditions. Geoderma 156, 43-47.

Bradford, M.M., 1976. A rapid and sensitive method for the quantitation of microgram quantities of protein utilizing the principle of protein-dye binding. Anal. Biochem. 72, 248-254.

Brausch, J.M., Smith, P.N., 2009. Pesticide resistance from historical agricultural chemical exposure in Thamnocephalus platyurus (Crustacea: Anostraca). Environ. Pollut. 157, 481-487.

Bromilow, R.H., Evans, A.A., Nicholls, P.H., 1999a. Factors affecting degradation rates of five triazole fungicides in two soil types: 2. Field studies. Pestic. Sci. 55, 1135-1142. Bromilow, R.H., Evans, A.A., Nicholls, P.H., 1999b. Factors affecting degradation rates of five triazole fungicides in two soil types: 1 . Laboratory incubations. Pestic. Sci. 55, 11291134.
Brown, S.A.E., McKelvie, J.R., Simpson, A.J., Simpson, M.J., 2010. 1H NMR metabolomics of 
earthworm exposure to sub-lethal concentrations of phenanthrene in soil. Environ.

613 Pollut. 158, 2117-2123.

614 Bundy, J., Sidhu, J., Rana, F., Spurgeon, D., Svendsen, C., Wren, J., Sturzenbaum, S., Morgan, A.J., Kille, P., 2008. "Systems toxicology" approach identifies coordinated metabolic responses to copper in a terrestrial non-model invertebrate, the earthworm Lumbricus rubellus. BMC Biol. 6, 25.

Calow, P., 1991. Physiological costs of combating chemical toxicants: Ecological implications. Comp. Biochem. Physiol. Part C Comp. Pharmacol. 100, 3-6.

Capowiez, Y., Bérard, A., 2006. Assessment of the effects of imidacloprid on the behavior of two earthworm species (Aporrectodea nocturna and Allolobophora icterica) using 2D terraria. Ecotoxicol. Environ. Saf. 64, 198-206.

Capowiez, Y., Dittbrenner, N., Rault, M., Triebskorn, R., Hedde, M., Mazzia, C., 2010. Earthworm cast production as a new behavioural biomarker for toxicity testing. Environ. Pollut. 158, 388-393.

Decaëns, T., Jiménez, J.J., 2002. Earthworm communities under an agricultural intensification gradient in Colombia. Plant Soil 240, 133-143.

Dittbrenner, N., Triebskorn, R., Moser, I., Capowiez, Y., 2010. Physiological and behavioural effects of imidacloprid on two ecologically relevant earthworm species (Lumbricus terrestris and Aporrectodea caliginosa). Ecotoxicology 19, 1567-1573. Donker, M.H., Zonneveld, C., Straalen, N.M., 1993. Early reproduction and increased reproductive allocation in metal-adapted populations of the terrestrial isopod Porcellio scaber. Oecologia 96, 316-323.

Edwards, C.A., Bohlen, P.J., 1996. Biology and Ecology of Earthworms, 3rd edition. ed. Chapman and Hall, London.

Farenhorst, A., Topp, E., Bowman, B.., Tomlin, A.., 2000. Earthworm burrowing and feeding activity and the potential for atrazine transport by preferential flow. Soil Biol. Biochem. 32, 479-488.

Fisker, K.V., Sørensen, J.G., Damgaard, C., Pedersen, K.L., Holmstrup, M., 2011. Genetic adaptation of earthworms to copper pollution: is adaptation associated with fitness costs in Dendrobaena octaedra? Ecotoxicology 20, 563-573.

Folch, J., Lees, M., Sloane-Stanley, G.H., 1957. A simple method for the isolation and purification of total lipids from animal tissues. J. Biol. Chem. 226, 497-509.

Fournier, D., Mutero, A., 1994. Modification of acetylcholinesterase as a mechanism of resistance to insecticides. Comp. Biochem. Physiol. C Pharmacol. Toxicol. Endocrinol. $108,19-31$.

Gevao, B., Semple, K.T., Jones, K.C., 2000. Bound pesticide residues in soils: a review. Environ. Pollut. 108, 3-14.

Groppa, M.D., Benavides, M.P., 2008. Polyamines and abiotic stress: Recent advances. Amino Acids 34, 35-45.

Gudbrandsen, M., Sverdrup, L.E., Aamodt, S., Stenersen, J., 2007. Short-term preexposure increases earthworm tolerance to mercury. Eur. J. Soil Biol. 43, S261-S267. Gupta, S.K., Sundararaman, V., 1991. Correlation between burrowing capability and AChE activity in the earthworm, Pheretima posthuma, on exposure to carbaryl. Bull. Environ. Contam. Toxicol. 46, 859-865.

Holmstrup, M., 2000. Field assessment of toxic effects on reproduction in the earthworms Aporrectodea longa and Aporrectodea rosea. Environ. Toxicol. Chem. 19, 1781-1787.

Holmstrup, M., Sørensen, J.G., Overgaard, J., Bayley, M., Bindesbøl, A.-M., Slotsbo, S., Fisker, K.V., Maraldo, K., Waagner, D., Labouriau, R., Asmund, G., 2011. Body metal 
concentrations and glycogen reserves in earthworms (Dendrobaena octaedra) from contaminated and uncontaminated forest soil. Environ. Pollut. 159, 190-197. Hugnes, M.S., Bull, C.M., Doube, B.M., 1996. Microcosm investigations into the influence of sheep manure on the behaviour of the geophagous earthworms Aporrectodea trapezoides and Microscolex dubuis. Biol. Fertil. Soils 22, 71-75. Jansen, M., Coors, A., Stoks, R., De Meester, L., 2011. Evolutionary ecotoxicology of pesticide resistance: a case study in Daphnia. Ecotoxicology 20, 543-551.

Jones, C.G., Lawton, J.H., Shachak, M., 1997. Positive and negative effects of organisms as physical ecosystem engineers. Ecology 78, 1946-1957.

Jordan, D., Miles, R.., Hubbard, V.., Lorenz, T., 2004. Effect of management practices and cropping systems on earthworm abundance and microbial activity in Sanborn Field: a 115-year-old agricultural field. Pedobiologia 48, 99-110.

Kanehisa, M., Goto, S., 2000. KEGG: Kyoto Encyclopedia of Genes and Genomes. Nucleic Acids Res. 28, 27-30.

Khodayari, S., Moharramipour, S., Larvor, V., Hidalgo, K., Renault, D., 2013. Deciphering the Metabolic Changes Associated with Diapause Syndrome and Cold Acclimation in the Two-Spotted Spider Mite Tetranychus urticae. PLoS ONE 8, e54025.

Krasensky, J., Jonak, C., 2012. Drought, salt, and temperature stress-induced metabolic rearrangements and regulatory networks. J. Exp. Bot. 63, 1593-1608.

Lamandé, M., Hallaire, V., Curmi, P., Pérès, G., Cluzeau, D., 2003. Changes of pore morphology, infiltration and earthworm community in a loamy soil under different agricultural managements. CATENA 54, 637-649.

Lankadurai, B., Nagato, E., Simpson, M., 2013. Environmental Metabolomics: An Emerging Approach to Study Organism Responses to Environmental Stressors. Environ. Rev.

Lavelle, P., Spain, A.V., 2001. Soil Ecology, Kluwer Academic Publishers. ed. Dordrecht, The Netherlands.

Liang, H., Qiu, J., Li, L., Li, W., Zhou, Z., Liu, F., Qiu, L., 2012. Stereoselective dissipation of epoxiconazole in grape (Vitis vinifera cv. Kyoho) and soil under field conditions. Chemosphere 87, 982-987.

Liu, Y.-J., Zaprasis, A., Liu, S.-J., Drake, H.L., Horn, M.A., 2011. The earthworm Aporrectodea caliginosa stimulates abundance and activity of phenoxyalkanoic acid herbicide degraders. ISME J. 5, 473-485.

Lukkari, T., Taavitsainen, M., Soimasuo, M., Oikari, A., Haimi, J., 2004. Biomarker responses of the earthworm Aporrectodea tuberculata to copper and zinc exposure: differences between populations with and without earlier metal exposure. Environ. Pollut. 129, 377-386.

Monard, C., Martin-Laurent, F., Vecchiato, C., Francez, A.J., Vandenkoornhuyse, P., Binet, F., 2008. Combined effect of bioaugmentation and bioturbation on atrazine degradation in soil. Soil Biol. Biochem. 40, 2253-2259.

Monard, C., Vandenkoornhuyse, P., Le Bot, B., Binet, F., 2011. Relationship between bacterial diversity and function under biotic control: the soil pesticide degraders as a case study. ISME J. 5, 1048-1056.

Mordaunt, C.J., Gevao, B., Jones, K.C., Semple, K.T., 2005. Formation of non-extractable pesticide residues: observations on compound differences, measurement and regulatory issues. Environ. Pollut. 133, 25-34.

Nicolai, A., Filser, J., Lenz, R., Valérie, B., Charrier, M., 2012. Composition of body storage compounds influences egg quality and reproductive investment in the land snail Cornu aspersum. Can. J. Zool. 90, 1161-1170. 
Nuutinen, V., 1992. Earthworm community response to tillage and residue management on different soil types in southern Finland. Soil Tillage Res. 23, 221-239. Paoletti, M.G., 1999. The role of earthworms for assessment of sustainability and as bioindicators. Agric. Ecosyst. Environ. 74, 137-155. Passeport, E., Benoit, P., Bergheaud, V., Coquet, Y., Tournebize, J., 2011. Epoxiconazole degradation from artificial wetland and forest buffer substrates under flooded conditions. Chem. Eng. J. 173, 760-765.

717 Pelosi, C., Barot, S., Capowiez, Y., Hedde, M., Vandenbulcke, F., 2013. Pesticides and 718 earthworms. A review. Agron. Sustain. Dev. 1-30.

719 Pook, C., Lewis, C., Galloway, T., 2009. The metabolic and fitness costs associated with metal resistance in Nereis diversicolor. Mar. Pollut. Bull. 58, 1063-1071.

Posthuma, L., 1990. Genetic Differentiation Between Populations of Orchesella cincta (Collembola) from Heavy Metal Contaminated Sites. J. Appl. Ecol. 27, 609-622. Posthuma, L., Van Straalen, N.M., 1993. Heavy-metal adaptation in terrestrial invertebrates: A review of occurrence, genetics, physiology and ecological consequences. Comp. Biochem. Physiol. C Pharmacol. Toxicol. Endocrinol. 106, 11-38. R Development Core Team, 2008. R: A language and environment for statistical computing. R Foundation for Statistical Computing, Vienna, Austria. Rhee, H.J., Kim, E.-J., Lee, J.K., 2007. Physiological polyamines: simple primordial stress molecules. J. Cell. Mol. Med. 11, 685-703. Ribera, D., Narbonne, J.F., Arnaud, C., Saint-Denis, M., 2001. Biochemical responses of the earthworm Eisenia fetida andrei exposed to contaminated artificial soil, effects of carbaryl. Soil Biol. Biochem. 33, 1123-1130.

733 Rodríguez-Castellanos, L., Sanchez-Hernandez, J.C., 2007. Earthworm biomarkers of 734 pesticide contamination: Current status and perspectives. J. Pestic. Sci. 32, 360-371. Schreck, E., Geret, F., Gontier, L., Treilhou, M., 2008. Neurotoxic effect and metabolic responses induced by a mixture of six pesticides on the earthworm Aporrectodea caliginosa nocturna. Chemosphere 71, 1832-1839.

Simpson, M.J., McKelvie, J.R., 2009. Environmental metabolomics: new insights into earthworm ecotoxicity and contaminant bioavailability in soil. Anal. Bioanal. Chem. 394, 137-149.

Smith, R.G., McSwiney, C.P., Grandy, A.S., Suwanwaree, P., Snider, R.M., Robertson, G.P., 2008. Diversity and abundance of earthworms across an agricultural land-use intensity gradient. Soil Tillage Res. 100, 83-88.

Söchtig, W., Larink, O., 1992. Effect of soil compaction on activity and biomass of endogeic lumbricids in arable soils. Soil Biol. Biochem. 24, 1595-1599.

Springett, J.A., Gray, R.A.J., 1992. Effect of repeated low doses of biocides on the earthworm Aporrectodea caliginosa in laboratory culture. Soil Biol. Biochem. 24, 17391744.

Thompson, A.R., 1971. Effects of nine insecticides on the numbers and biomass of earthworms in pasture. Bull. Environ. Contam. Toxicol. 5, 577-586.

Wiegand, C., Pehkonen, S., Akkanen, J., Penttinen, O.-P., Kukkonen, J.V.K., 2007. Bioaccumulation of paraquat by Lumbriculus variegatus in the presence of dissolved natural organic matter and impact on energy costs, biotransformation and antioxidative enzymes. Chemosphere 66, 558-566.

Wiegand, C., Pflugmacher, S., Giese, M., Frank, H., Steinberg, C., 2000. Uptake, Toxicity, and Effects on Detoxication Enzymes of Atrazine and Trifluoroacetate in Embryos of Zebrafish. Ecotoxicol. Environ. Saf. 45, 122-131.

Yasmin, S., D'Souza, D., 2010. Effects of Pesticides on the Growth and Reproduction of 
Earthworm: A Review. Appl. Environ. Soil Sci. Vol. 2010, 1-9.

Fig1

Metabolic rate ( $\mu \mathrm{g} \mathrm{CO}_{2} \mathrm{~g}^{-1}$ worm (fresh weight) hour ${ }^{-1}$ ) of pre-exposed (square) and naïve (triangle) A. caliginosa exposedto Epoxiconazole (solid symbols, full lines) or not exposed (open symbols, dashed lines) at day 0,7 and 28. Mean values ( $\mathrm{N}=5$ worms per group) are presented with standard deviations as error bars. Significant differences are indicated with * between exposed and control worms and \# between populations at each sampling time. Different letters (a or b) denote statistical differences between sampling times within the same group.

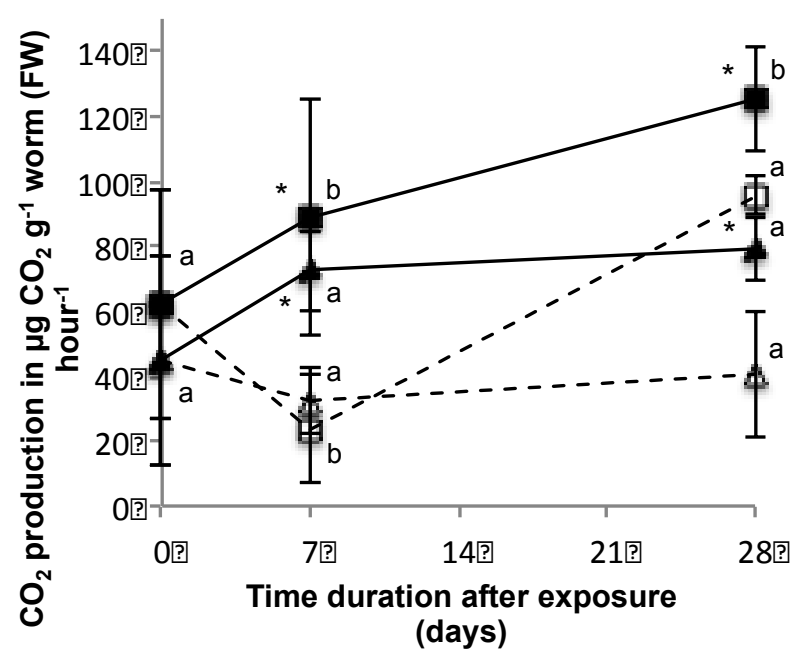


Mean cast production (in $\mathrm{g}$ dry cast weight $\mathrm{g}^{-1}$ earthworm body mass day ${ }^{-1}$ ) of pre-exposed and naïve Aporrectodea caliginosa after exposure to epoxiconazole for 7 and 28 days $(n=8)$. Error bars are standard deviations (SD). * indicates significant differences between exposed and control groups (student-t-test, ${ }^{\circ} \mathrm{p}<0.1$, $* \mathrm{p}<0.05, * * \mathrm{p}<0.01)$ and \# between earthworm populations.

788

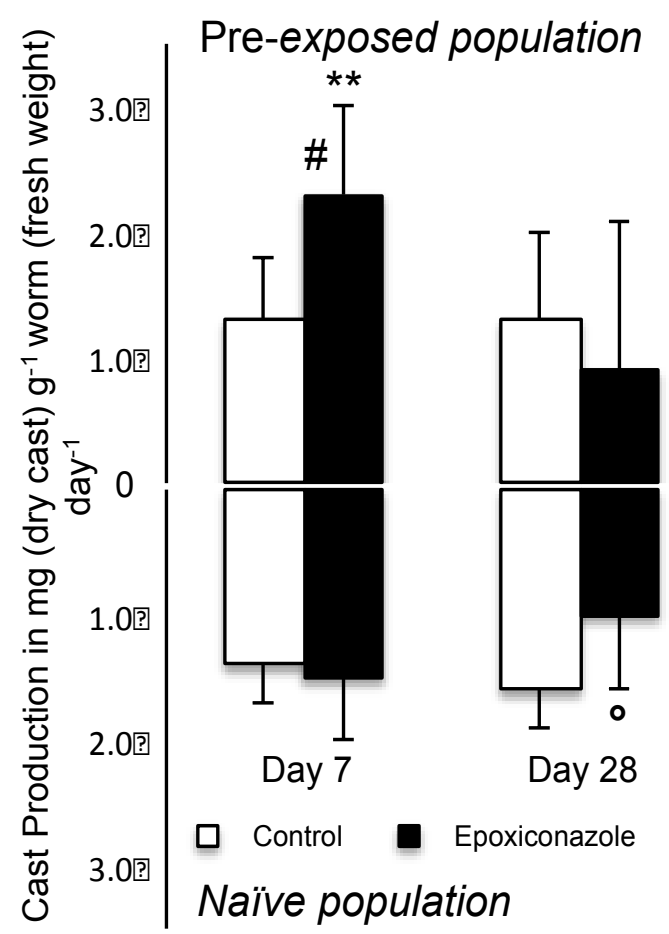



naïve A. caliginosa exposedto Epoxiconazole at day 7 and 28. Mean values ( $\mathrm{N}=5$ worm per group) are presented with standard deviations as error bars. Significant differences are indicated with * between exposed and control worms (Student-t-tests, $\mathrm{p}<0.1$ ).

807

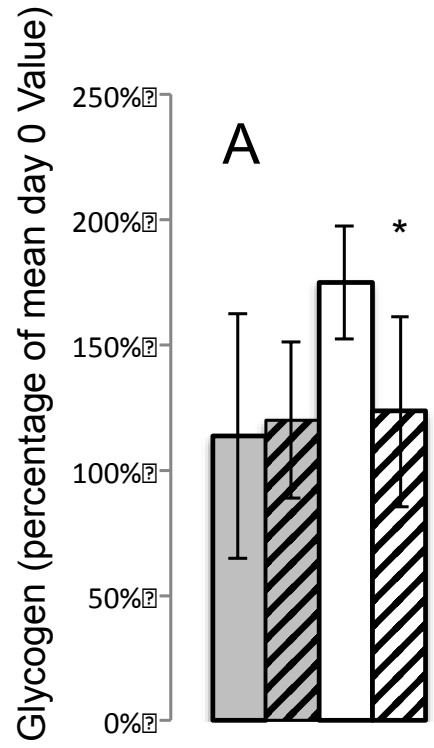

Day 7

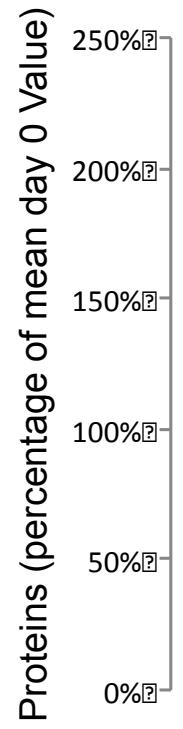

808
C

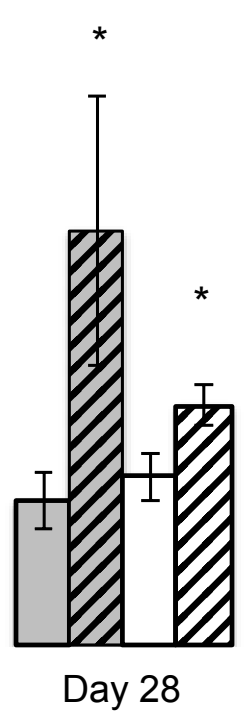

B

$200 \%$ ?

$150 \%$ 回

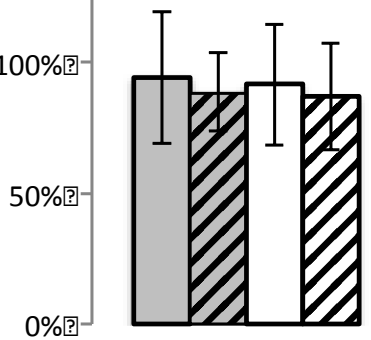

Day 7

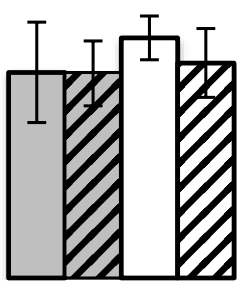

Day 28
Control - pre-exposed

Epoxi - pre-exposed

Control - Naîve

Epoxi- Naïve 
Principal Component Analysis of metabolites data (22 variables) showing relationship between metabolite profiles and epoxiconazole exposure along time. A, B: Scores plots for conventional population (Axes 2 and 3 ) and organic population (Axes 1 and 2). Data are shown as crosses for both exposed and control groups means \pm standard error of the mean (SEM). Exposed and Control groups are joined by time order with dashed lines. C, D: Loadings plots for individual metabolites in the conventional population (axes 2 and 3) and in the organic population (axes 1 and 2). Metabolites are identified by their abbreviations and colored by functional groups listed in supplementary material (Table S4).

823

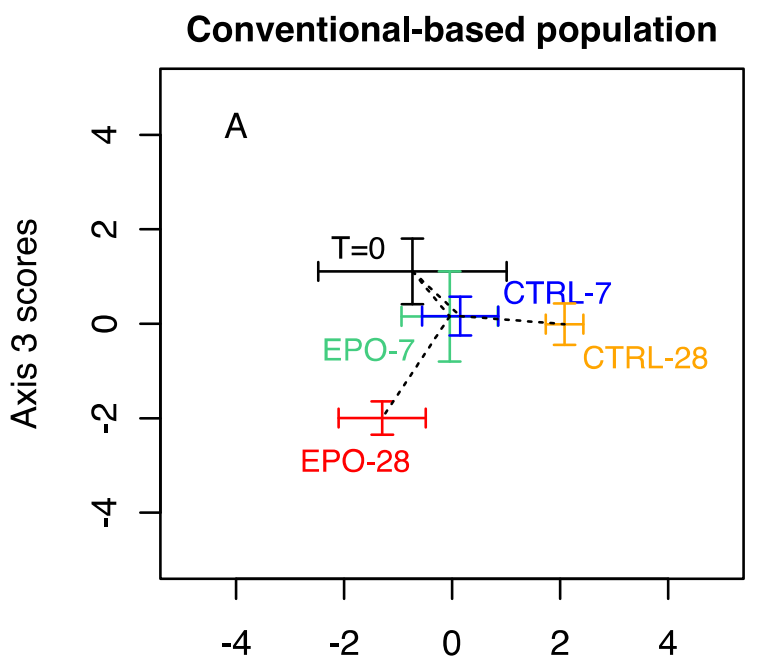

Axis 2 scores

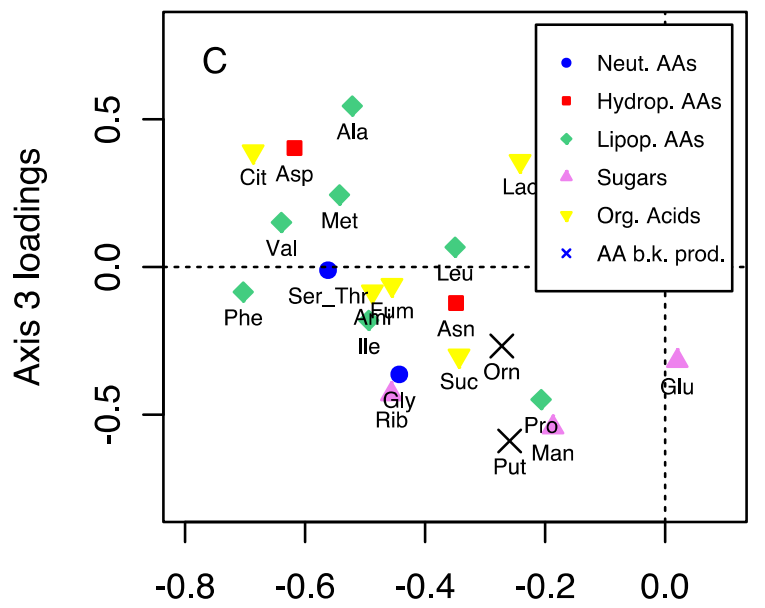

Axis 2 loadings

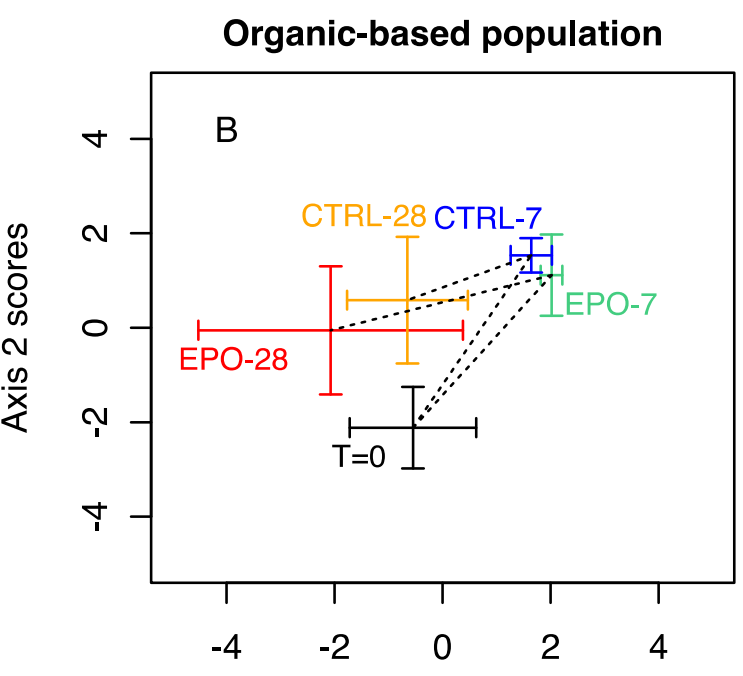

Axis 1 scores

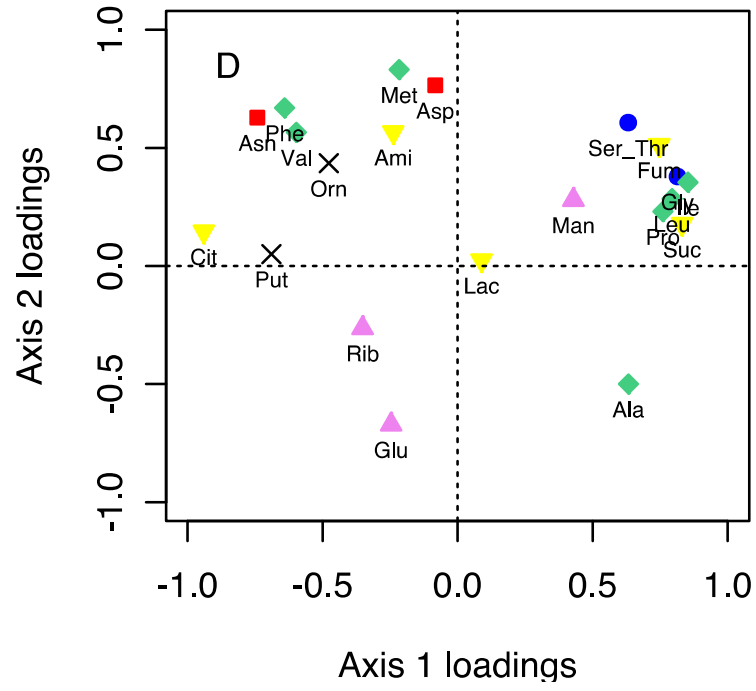


831 Metabolite functional group responses to epoxiconazole, concentrations expressed as percentage of mean control

832 value. A and E: amino-acids (blue=neutral, black=lipophilic, red=hydrophilic) B and F: sugars (blue=glucose,

833 black=mannose, red=ribose) $\mathrm{C}$ and G: Krebs' cycle intermediates (blue $=$ aminobutyrate, black $=$ citrate, red $=$

834 fumarate, green = lactate, violet $=$ succinate) $\mathrm{D}$ and $\mathrm{H}$ : amino acids degradation products (black=ornithine,

835 blue=putrescine). * indicates significant differences between exposed and control groups (Student t-tests, $\mathrm{p}<0.1)$.
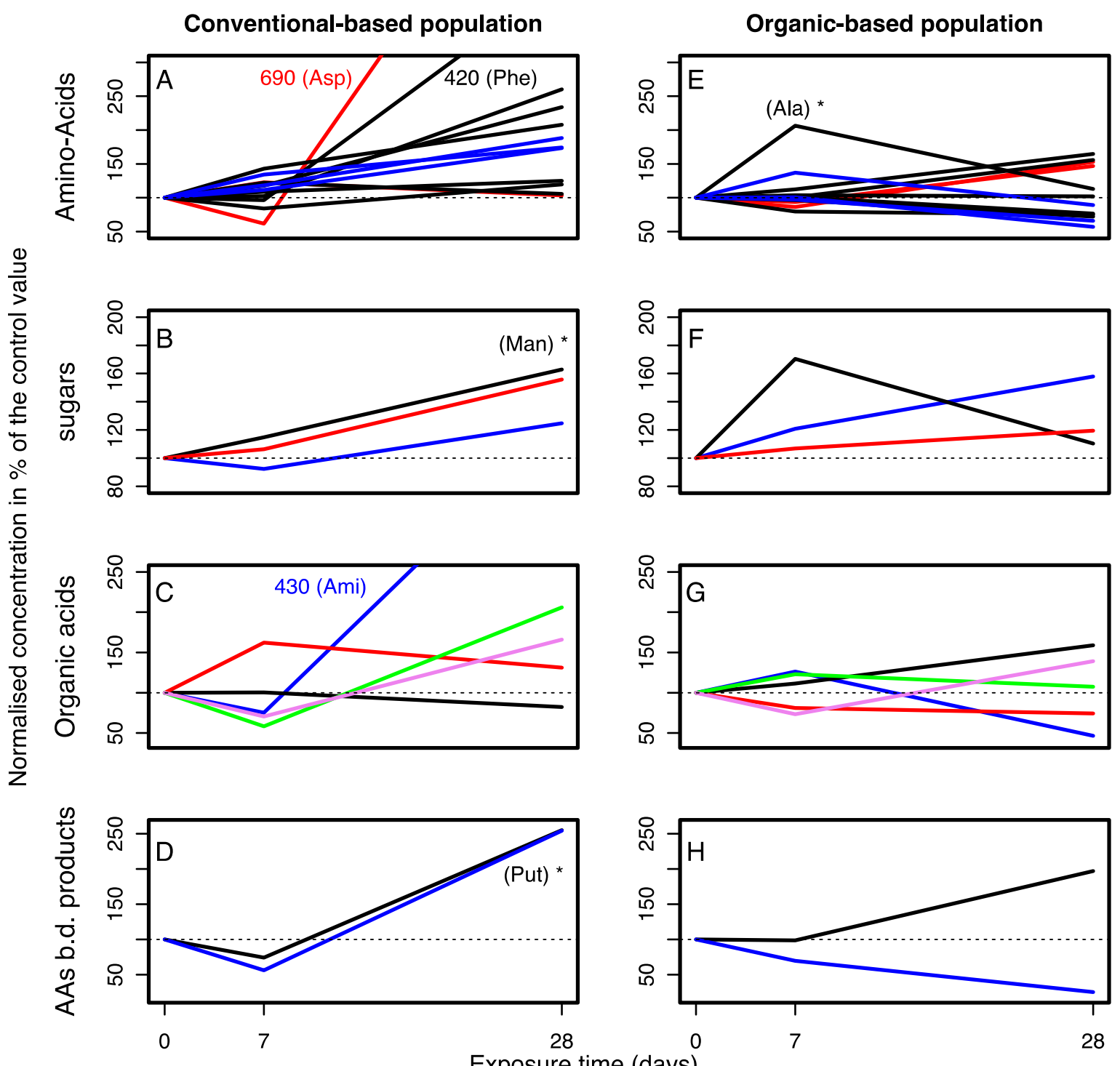